\title{
Surface Characterisation of Titanium Alloy Implants
}

\section{Journal Article}

\section{Author(s):}

Wieland, M.; Sittig, C.; Textor, M.; Birchler, F.; Blum, J.; Ha, S.-W.; Keller, B.A.; Wintermantel, E.; Spencer, N.D.

Publication date:

1996

Permanent link:

https://doi.org/10.3929/ethz-b-000422543

\section{Rights / license:}

In Copyright - Non-Commercial Use Permitted

\section{Originally published in:}

Biomedizinische Technik 41(s1), https://doi.org/10.1515/bmte.1996.41.s1.446 


\title{
Surface Characterisation of Titanium Alloy Implants
}

\author{
Wieland M., Sittig C. ${ }^{1)}$, Textor M. ${ }^{1)}$, Birchler F. ${ }^{2)}$, Blum J. ${ }^{2)}$, Ha S.-W. ${ }^{2)}$, Keller B.A., \\ Wintermantel E. ${ }^{2)}$, Spencer N.D. ${ }^{1)}$
}

\author{
Swiss Federal Laboratories for Materials Testing and Research, Überlandstr. 129, CH-8600 Dübendorf \\ 1) Laboratory of Surface Science and Technology, Department of Materials, ETH Zürich, Sonneggstr. 5, CH-8092 Zürich \\ ${ }^{2)}$ Chair of Biocompatible Materials Science and Engineering, Department of Materials, ETH Zürich, Wagistr. 23, \\ CH-8952 Schlieren
}

\section{INTRODUCTION}

The excellent biocompatibility of titanium and some of its alloys, used for orthopædic and dental implants, is intimately connected with the properties of the surface in contact with the biological environment [1]. However, there is still a lack of scientific understanding as to how the chemical composition and topography of the titanium surface influences the performance of the implant in a biological environment. In this study the chemical composition and the topography of the surface of commercial pure (cp) Ti, Ti6Al7Nb (in wt.\%), Ti6Al4V (in wt.\%) and for comparison CoCrMo as well as their effect on the viability of the MC3T3E1 osteoblastic cell-line were investigated.

\section{MATERIALS AND METHODS}

Materials: All investigations were performed on discs, $15 \mathrm{~mm}$ in diameter and $1 \mathrm{~mm}$ in thickness for cpTi and $5 \mathrm{~mm}$ in thickness for all alloys. cpTi and Ti6Al7Nb samples were mechanically polished (p) to a mirror finish. The polished cpTi and Ti6AlTNb samples were pretreated by double ultrasonic cleaning in hexane, acetone and ethanol $10 \mathrm{~min}$ for each, with intermediate rinsing in the subsequent solvent. Afterwards samples were rinsed in ultrapure water $(18.2 \mathrm{M} \Omega \mathrm{cm})$ and passivated in $30 \% \mathrm{HNO}_{3}$ for $1 \mathrm{~h}$. Finally, samples were ultrasonically rinsed in ultrapure water, dried with $\mathrm{N}_{2}$, plasma cleaned in an $\mathrm{O}_{2}$ plasma ( $0.42 \mathrm{mbar}, 2 \mathrm{~min}$.), stored in ultrapure water for $2 \mathrm{~h}$, dried with $\mathrm{N}_{2}$ and packed in Al-foil. Polished samples were sterilized at $180^{\circ} \mathrm{C}$ for 3h. Ti6Al7Nb, Ti6Al4V and CoCrMo were either finely sandblasted (fsb) with glass beads or roughly sandblasted (rsb) with alumina and subsequently cleaned ultrasonically in a detergent. The sandblasted samples were sterilized by $\gamma$-irradiation.

Methods: X-ray photoelectron spectroscopy (XPS) data were obtained on a Specs Model SAGE 100 using unmonochromatized $\mathrm{Mg} K_{\alpha}$ radiation at $300 \mathrm{~W}(12 \mathrm{kV}$, $25 \mathrm{~mA}$ ) with an electron detector pass energy of $50 \mathrm{eV}$ for survey spectra and $14 \mathrm{eV}$ for high-resolution spectra. The topography was investigated with a UBM System for optical surface rouhgness measurement using a red laser. Line profiles were obtained with a $1.75 \mathrm{~mm}$,
1400 Points $/ \mathrm{mm}$ line for polished, $5.6 \mathrm{~mm}$, 500 Points $/ \mathrm{mm}$ for finely sandblasted and $12 \mathrm{~mm}$, 150 Points/mm for roughly sandblasted samples.

Cell culture testing: Cell culture tests were carried out with MC3T3E1 osteoblastic cell-line cultured in MEM alpha medium (Gibco) containing 5\% fetal bovine serum, $10 \mathrm{mM} \quad \beta$-glycerophosphate, $0.25 \mathrm{mM}$ ascorbic acid, $0.2 \%$ gentamycin and $0.6 \%$ fungizone, at $37^{\circ} \mathrm{C}, 5 \% \mathrm{CO}_{2}$ and $95 \%$ relative humidity. For experiments, the cells were harvested by trypsinization, followed by seeding on polished and sandblasted specimens as well as on $\mathrm{NaOH}-$ etched glass controls. After 48 hours of incubation, cell viability was determined with a thiazolylblue tetrazoliumbromide (MTT) assay [2]. MTT-formazan, produced by intracellular succinate dehydrogenase, was extracted with ethanolic HEPES/NaCl. The solutions were transferred to MicroWell plates (Nunc) and the optical density of the solution was measured at $560 \mathrm{~nm}$ using a multiwell reader (Rainbow, SLT, Austria). A second series of test samples was fixed with $3 \%$ glutaraldehyde in PBS and prepared for scanning electron microscopy (SEM).

\section{RESULTS AND DISCUSSION}

Surface Roughness: UBM measurements (Table1) indicated that there were small differences between polished cpTi and polished Ti6Al7Nb surfaces. Sandblasted Ti6Al4V samples were smoother than corresponding Ti6Al7Nb samples and CoCrMo surface roughnesses

\begin{tabular}{|l|c|c|c|}
\hline Alloy & Surface $^{\mathrm{l}}$ & $\mathrm{R}_{\mathrm{a}}[\mu \mathrm{m}]^{2)}$ & $\mathrm{R}_{\mathrm{q}}[\mu \mathrm{m}]^{2)}$ \\
\hline cpTi $^{2)}$ & $\mathrm{p}$ & $0.038 \pm 0.005$ & $0.050 \pm 0.007$ \\
\hline Ti6Al7Nb & $\mathrm{p}$ & $0.015 \pm 0.007$ & $0.030 \pm 0.014$ \\
\hline Ti6Al7Nb & fsb & $1.32 \pm 0.18$ & $1.93 \pm 0.46$ \\
\hline Ti6Al7Nb & rsb & $4.05 \pm 0.68$ & $5.23 \pm 0.36$ \\
\hline Ti6Al4V & fsb & $1.00 \pm 0.08$ & $1.31 \pm 0.10$ \\
\hline Ti6Al4V & rsb & $3.78 \pm 0.29$ & $5.07 \pm 0.49$ \\
\hline CoCrMo & fsb & $0.60 \pm 0.04$ & $0.79 \pm 0.06$ \\
\hline CoCrMo & rsb & $2.88 \pm 0.14$ & $3.89 \pm 0.27$ \\
\hline
\end{tabular}

Table 1: Roughness of cpTi and its alloys and CoCrMo surfaces. ${ }^{\text {" }} p=$ polished, $f s b=$ finely sandblasted $r s b=$ roughly sandblasted $\quad{ }^{2)} n=3$; mean values \pm standard deviations 
were smaller than that of Ti6Al4V surfaces. However,there was a statistically significant difference between the different type of surfaces.

Surface Composition: XPS analysis of untreated polished cpTi and Ti6Al7Nb surfaces indicated the presence of typical atmospheric contaminants, especially $\mathrm{C}$ and to some extent $O$ (Table 2), as well as low-concentration contaminants such as $\mathrm{Si}, \mathrm{Pb}, \mathrm{Na}, \mathrm{Ca}$ and $\mathrm{Zn}(<1.0$ at.\%) from the mechanical polishing. After pretreatment, XPS data indicated clean surfaces with reduced $C$ values and

\begin{tabular}{|c|c|c|c|c|}
\hline & $\mathrm{cpTi}^{1)}$ & $\mathrm{cpTi} i^{2)}$ & Ti6Al7Nb $^{1)}$ & Ti6Al7Nb ${ }^{2)}$ \\
\hline $\mathrm{Ti}$ & $18.5 \pm 1.6$ & $26.7 \pm 0.9$ & $19.5 \pm 0.4$ & $22.2 \pm 0.9$ \\
\hline $\mathrm{Al}$ & - & - & $4.1 \pm 0.3$ & $4.5 \pm 0.5$ \\
\hline $\mathrm{Nb}$ & - & - & $0.9 \pm 0.1$ & $1.4 \pm 0.1$ \\
\hline 0 & $47.0 \pm 1.9$ & $55.7 \pm 1.1$ & $52.4 \pm 0.9$ & $56.1 \pm 1.5$ \\
\hline C & $31.1 \pm 2.1$ & $17.4 \pm 1.5$ & $18.3 \pm 1.0$ & $15.9 \pm 1.6$ \\
\hline $\mathbf{N}$ & - & traces & - & traces \\
\hline
\end{tabular}

Table 2: XPS analysis (at.\%) of polished cpTi and Ti6Al7Nb samples ( $n=5$ for each surface; means \pm standard deviations). "untreated, ${ }^{2)}$ pretreated

only traces of $\mathrm{N}$ from the nitric acid treatment. The cleaned surfaces showed an atomic concentration ratio of $0.66 \pm 0.08$ for $\mathrm{C} / \mathrm{Ti}$ and $2.09 \pm 0.04$ for $\mathrm{O} / \mathrm{Ti}$ compared to $\mathrm{C} / \mathrm{Ti}=1.71 \pm 0.25$ and $\mathrm{O} / \mathrm{Ti}=2.55 \pm 0.14$ for untreated cpTi surfaces. These results correlated with ToF-SIMS spectra (data not shown).

The oxide-layer thickness, calculated from the XPS intensity ratio $\mathrm{Ti}$ (metal)/Ti(oxide), was about 4 - 5nm for untreated polished cpTi and Ti6Al7Nb surfaces [3] and 5 $6 \mathrm{~nm}$ for the pretreated polished surfaces.

On finely and roughly sandblasted surfaces, $\mathrm{Si}, \mathrm{Na}, \mathrm{Ca}$ and $\mathrm{Al}$ from the sandblasting processes were found, as well as the contaminants $\mathrm{C}, \mathrm{O}$ and $\mathrm{N}$ (Table 3 ). $\mathrm{Nb}$ was only detected on the roughly surface of Ti6Al7Nb. $\mathrm{V}$ in Ti6Al4V could not be detected (using unmonochromatized $\mathrm{Mg} K_{\alpha}$ radiation).

\begin{tabular}{|l|c|c|c|c|}
\hline & Ti6Al7Nb $^{\prime \prime}$ & Ti6Al7Nb $^{21}$ & Ti6Al4V $^{\prime \prime}$ & Ti6Al4V $^{21}$ \\
\hline $\mathrm{Ti}$ & $3.3 \pm 0.2$ & $9.5 \pm 0.8$ & $3.8 \pm 0.7$ & $8.9 \pm 0.9$ \\
\hline $\mathrm{Al}$ & $4.5 \pm 0.3$ & $18.4 \pm 1.2$ & $3.8 \pm 0.4$ & $15.3 \pm 2.9$ \\
\hline $\mathrm{Nb}$ & - & $0.6 \pm 0.1$ & - & - \\
\hline $\mathrm{V}$ & - & - & - & - \\
\hline $\mathrm{O}$ & $52.6 \pm 1.0$ & $52.2 \pm 0.6$ & $49.7 \pm 1.5$ & $49.4 \pm 2.6$ \\
\hline $\mathrm{C}$ & $13.8 \pm 1.7$ & $16.8 \pm 1.3$ & $19.7 \pm 2.1$ & $23.2 \pm 5.9$ \\
\hline $\mathrm{Si}$ & $17.4 \pm 1.0$ & - & $15.3 \pm 0.4$ & - \\
\hline $\mathrm{Na}$ & $6.0 \pm 0.4$ & $2.5 \pm 0.5$ & $5.9 \pm 0.4$ & $2.8 \pm 0.6$ \\
\hline $\mathrm{Ca}$ & $2.4 \pm 0.3$ & - & $1.7 \pm 0.2$ & traces \\
\hline $\mathrm{N}$ & - & - & traces & traces \\
\hline
\end{tabular}

Table 3: XPS analysis (at.\%) of sandblasted Ti6Al7Nb and Ti6Al4V samples ( $n=5$ for each surface; mean values \pm standard deviations). "finely sandblasted, " roughly sandblasted
Cell culture testing: On the Ti-alloy samples cell spreading varied with the different surface topographies. The cells on the roughly sandblasted surfaces were evenly spread and were often seen to form bridges between domains of the surface irregularities. On the finely sandblasted surfaces cell spreading appeared more regular and smoother. Figure 1 is a representative graph of one series out of three. It shows the activity of succinatedehydrogenase on the different substrates. On the Ti6Al7Nb surfaces higher activity was observed with increasing roughness indicating a possible influence of surface topography on cell viability. However, no major influence of topography was observed on the different type of CoCrMo and Ti6Al4V surfaces.

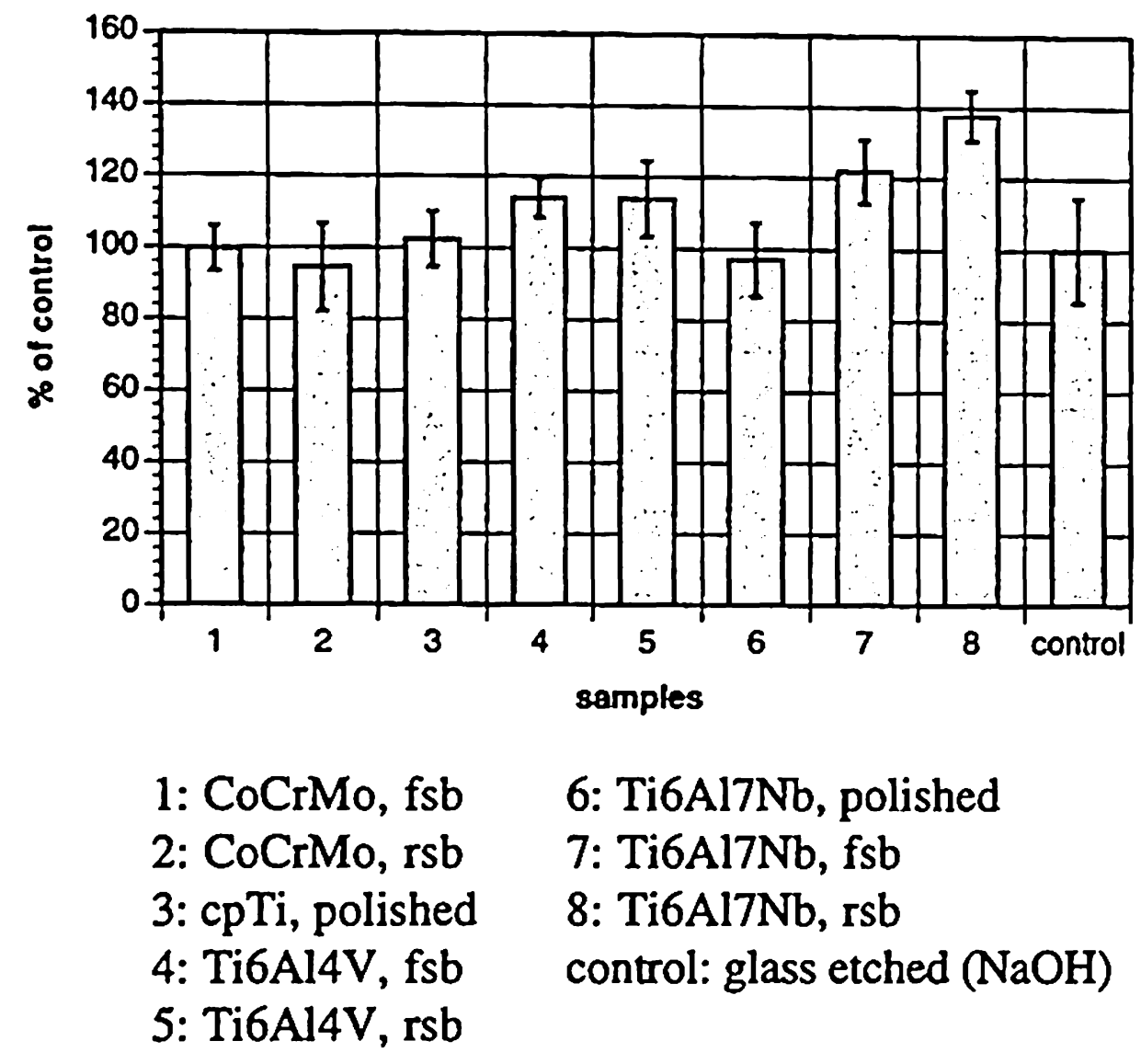

Figure 1: Activity of succinate-dehydrogenase (MTT) on CoCrMo, cpTi and Ti-alloys surfaces $(n=4-6)$.

\section{CONCLUSIONS}

The preliminary results of the cell culture testing in this study indicate that topographical characteristics of roughly sandblasted Ti6Al7Nb surface enhance the viability of osteoblast-like cells. More detailed studies conceming osteoblast differentiation will be subject of further investigations.

\section{ACKNOWLEDGMENT}

The authors would like to thank Mr. P.-H. Vallotton of Straumann Institute, $\mathrm{CH}-4437$ Waldenburg and Mr. M. Windler of Sulzer Orthopedics, CH-8404 Winterthur for the materials. This study was financially supported by Priority Program of Materials (PPM).

\section{REFERENCES}

[1] B.D. Ratner; Surface Characterisation of Biomaterials, Elsevier Science Publishers B.V., Amsterdam(1988)

[2] T. Mosmann; Immunol. Methods 65, 55-63 (1983)

[3] B.W. Callen; Progr. Surf. Sci 50, 269-279 (1995) 